\title{
ANALISIS PANGSA PASAR DAN DAYA SAING CPO INDONESIA DI UNI EROPA
}

\author{
Dian Widyaningtyas ${ }^{1}$, Tri Widodo ${ }^{2}$ \\ ${ }^{1}$ Fakultas Ekonomi, Ilmu Sosial, dan Humaniora. Universitas Aisyiyah Yogyakarta ${ }^{2}$ Fakultas \\ Ekonomika dan Bisnis, Universitas Gadjah Mada (UGM) \\ Email: dianoer@gmail.com
}

\begin{abstract}
Commodities of palm oil play a strategic role in the Indonesia's economy. In this study we concern on the competitiveness of Indonesia's Crude Palm Oil (CPO) industry and effectiveness of the potential market for Indonesia's CPO in Uni Europe (UE). The utilization of $C P O$ as biofuels, encouraging an significant increased of demand for CPO in UE. This study is also addressed to determine the Indonesian CPO performance among other palm oil producer country. We used the revealed comparative advantage ( $R C A)$ dan market share index (MSI) methods in analysing the competitiveness level. Our results showed, in 2014, export performance of Indonesia's CPO increased. It was showed by the value of $R C A>1$. Indonesia has competitiveness of $C P O$, because of the increased export volume of $C P O$ and it's derivates product to the major importer countries, such as $U E$. However, the average of RCA analysis in 2007-2014 indicate the lower performance of Indonesia's CPO exports compared to the other main CPO exporter, Malaysia. Thus, from the MSI analysis we found that Italy is a potential market for Indonesia's palm oil exports, based on the fact that Indonesia's CPO dominated the Italian market in the last seven years. The value of Indonesia's market share was far above the competitor.
\end{abstract}

Keyword: Competitiveness, crude palm oil, comparatif advantage.

\section{Pendahuluan}

Komoditi kelapa sawit mempunyai peran strategis dalam perekonomian Indonesia. Industri kelapa sawit merupakan penghasil devisa terbesar setelah migas. Perkembangan konsumsi kelapa sawit menunjukkan tren yang meningkat di dunia. Indonesia merupakan negara penghasil CPO terbesar di dunia, diikuti Malaysia, dan Thailand. Perkebunan kelapa sawit Indonesia juga menunjukkan perluasan area. Pada tahun 2014 tercatat persebaran terluas di Indonesia bagian barat, yaitu provinsi Riau (2,30 juta Ha) dan Sumatera Utara (1,39 juta Ha). Luas total area perkebunan kelapa sawit pada tahun 2015 seluas 11,44 juta Ha, meningkat dari 10,7 juta Ha pada tahun 2014 (Dirjenbun, 2015).
Pangsa pasar CPO Indonesia dewasa ini, tidak hanya terfokus pada kawasan asia seperti India dan China, tetapi telah berkembang pada pasar Uni Eropa (UE) dan Timur Tengah. Permintaan CPO pada negaranegara di Amerika dan UE menunjukkan peningkatan yang signifikan. Pada pasar UE memperlihatkan peningkatan karena semakin banyak perusahaan-perusahaan di Eropa yang menggunakan CPO sebagai bahan mentah produksi, bahan pembuatan kosmetik, dan oleochemical. Selain itu pemanfaatan biofuel sebagai energi alternatif bahan bakar mendorong peningkatan konsumsi CPO pada pasar UE. Biofuel dikembangkan untuk mengatasi kelangkaan energi. Pemanfaatan minyak sawit sebagai alternatif pengganti bahan bakar akan memberikan beberapa 
keuntungan. Bahan dasar untuk memproduksi biofuel di UE menggunakan $\mathrm{CPO}$ dari Indonesia. Hal ini mendorong permintaan ekspor CPO Indonesia ke UE terus meningkat dari tahun ke tahun.

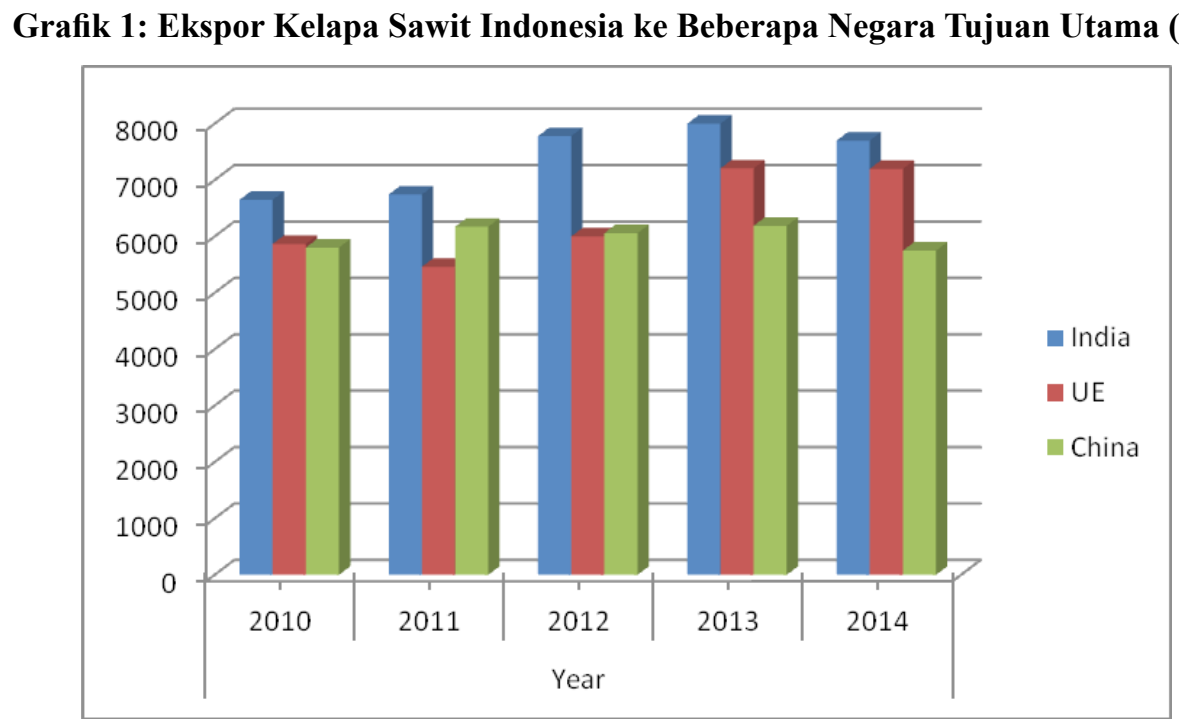

Sumber: BPS, Statistik Kelapa Sawit Indonesia, 2014.

Kelapa sawit merupakan tanaman perkebunan yang tumbuh pesat jika dibandingkan dengan tanaman perkebunan lain seperti kopi maupun kakao. Berdasarkan indeks daya saing Revealed Comparative Advantage (RCA), CPO dalam Harmonized System (HS) 2 digit berada di urutan kedua dari produk Indonesia yang mempunyai indeks tertinggi sejak tahun 2000 hingga 2011 (Kemendag, 2013).

Penelitian ini akan menganalisis pangsa pasar dan daya saing ekspor dari CPO Indonesia di UE. Indikator yang digunakan adalah Revealed Comparative Advantage $(R C A)$ untukmenentukan daya saingkomoditas CPO pada dua negara eksportir utama yaitu Indonesia dan Malaysia, sebagai kompetitor. Sementara, perdagangan di pangsa pasar UE akan dianalisis menggunakan Market Share Indeks (MSI) pada dua negara importir utama yaitu Belanda dan Itali. Analisis ini akan memberikan interpretasi awal mengenai posisi komoditas CPO Indonesia di pasar UE. Penelitian ini akan memberikan kontribusi dalam menghadapi persaingan industri CPO yang semakin kompetitif.

\section{Tinjauan Pustaka}

1. Daya saing

Dasar pemikiran yang melandasi penelitian ini bahwa suatu industri harus mempunyai daya saing agar bisa bertahan dalam persaingan industri jangka panjang. Suatu industri harus mempunyai keunggulan agar dapat menghadapi tantangan pesaingnya.

Pangsa pasar merupakan keseluruhan permintaan suatu barang pada suatu wilayah. Segmentasi pasar biasanya digunakan untuk mengidentifikasi, menentukan target pelanggan, dan memberikan data pendukung untuk elemen rencana pemasaran. Market share merupakan bagian pasar yang dikuasai oleh suatu perusahaan dan seluruh potensi jual. Market share biasanya dinyatakan dalam bentuk persentase total.

Keunggulan komparatif merupakan suatu ukuran relatif yang akan menunjukkan keunggulan suatu komoditi di pasar. Konsep ini diperkenalkan pada tahun 1817 oleh David Ricardo. Teori keunggulan komparatif menjadi dasar utama dilakukannya perdagangan internasional antarnegara. Pada tahun 1936 teori keunggulan komparatif disempurnakan oleh Haberler dengan menggunakan opportunity cost theory (teori 
biaya imbangan), yaitu suatu negara dikatakan mempunyai keunggulan komparatif apabila negara tersebut mempunyai opportunity cost lebih rendah dalam memproduksi suatu barang (Salvatore, 1997). Selanjutnya, teori perdagangan modern dikembangkan oleh Hecksler-Ohlin. Teori H-O ini lebih dikenal dengan The Proportional Factor Theory. Teori ini memberikan penjelasan mengenai penyebab perbedaan produktivitas suatu negara akibat jumlah faktor produksi yang dimiliki yang kemudian menyebabkan terjadinya perbedaan harga suatu produk.

Indikator yang dapat digunakan untuk mengukur daya saing produk adalah Revealed Comparative Advantage (RCA). Konsep keunggulan komparatif RCA diperkenalkan oleh Bela Balassa pada tahun 1965. Indeks RCA dapat menunjukkan adanya perubahan dalam keunggulan komparatif. RCA dapat menjelaskan kekuatan daya saing dari produk ekspor Indonesia terhadap produk sejenis dari negara lain. Dasar pemikiran konsep ini adalah bahwa hasil dari kinerja ekspor ditentukan oleh daya saing relatif terhadap produk sejenis dari negara lain. Hal ini mengungkapkan adanya keunggulan komparatif suatu negara khususnya pada faktor ketersediaan bahan baku industri.

\section{Permintaan CPO}

Permintaan CPO di pasar Uni Eropa (UE) menunjukkan peningkatan signifikan. Belanda dan Itali merupakan dua negara pengimpor CPO terbesar di UE. Di tahun 2014, nilai total impor CPO Belanda mencapai 1,898,704 ribu US\$ dan nilai total impor CPO Itali mencapai 711,986,739 US\$ (UnComtrade, 2014).

Pada tahun 2009, ekspor CPO Indonesia ke negara-negara UE sebesar 3,6 juta ton. Data Gapki mencatat, ekspor CPO Indonesia ke negara-negara UE mengalami kenaikan sebesar 2,6\% pada tahun 2015 dari volume ekspor tahun lalu. Permintaan CPO dari UE pada tahun 2015 tercatat 4,23 juta ton. Hal ini menjadikan Eropa sebagai salah satu pasar ekspor utama bagi CPO Indonesia (Gapki, 2015). UE merupakan salah satu pasar alternatif yang strategis dibandingkan dengan pasar-pasar yang lain. UE sedang mengembangkan produk turunan $\mathrm{CPO}$ yaitu Biodiesel. UE merupakan produsen dan pasar biodiesel terbesar di dunia dengan target pasar sebesar $5,75 \%$ dari total konsumsi minyak diesel untuk transportasi pada tahun 2010. Pesatnya pertumbuhan produksi biodiesel UE disebabkan tingginya pertumbuhan produksi di negara produsen biodiesel terbesar yaitu Jerman, Perancis, dan Italia. Dari sisi demografi, peningkatan jumlah penduduk UE secara langsung dapat meningkatkan kebutuhan akan minyak makan (edible oil) UE. Sementara produksi minyak makan lokal mengalami penurunan, sehingga pemanfaatan CPO difokuskan pada produk turunan utama yaitu minyak makan. Data Oil World mencatat, produksi minyak makan UE menurun hingga 16,8 juta ton pada tahun 2003. Kemudian produksi minyak makan UE meningkat hingga mencapai 18,9 juta ton pada tahun 2009, seiring meningkatnya kebutuhan akan minyak makan UE (Oilworld, 2010).

Negara-negara tujuan ekspor utama CPO Indonesia di UE adalah Belanda, Itali, dan Spanyol.

Tabel 1: Negara Tujuan Ekspor CPO Indonesia di Uni Eropa (ton)

\begin{tabular}{lccc}
\hline \multicolumn{1}{c}{ Negara } & 2012 & 2013 & 2014 \\
\hline Belanda & 813.123 & 1.094 .673 & 866.087 \\
Italia & 567.254 & 683.552 & 601.648 \\
Spanyol & 260.994 & 421.572 & 276.017 \\
\hline
\end{tabular}

Sumber: diolah BPS dan Kemendag.

Uni Eropa mulai menjadi pasar utama bagi bagi ekspor CPO Indonesia sejak tahun 2008. Permintaan CPO UE mengalami peningkatan tujuh tahun terakhir. Uni Eropa merupakan pasar strategis bagi produk hasil hutan dan CPO Indonesia. Produk Indonesia akan bisa merambah pasar Eropa asalkan memiliki standar produk, baik standar kualitas maupun standar proses produksi lingkungan. UE salah satu pasar alternatif utama dibandingkan dengan pasar-pasar yang lain. Selain itu, pada akses pasar yang lebih luas, Indonesia dan 
UE saling membutuhkan dalam kerjasama perdagangan dan investasi. Perekonomian Indonesia dan UE saling melengkapi. Dari sisi kemampuan produksi Indonesia dan penguasaan teknologi serta capital yang dimiliki UE. Hal tersebut bersinergi dalam membentuk capacity building yang kuat antara Indonesia dan UE. Beberapa kebijakan impor CPO UE antara lain pajak progresif, anti dumping, dan Renewable Energy Directive (RED). Kebijakan RED UE mendapat respons dengan diterapkannya Indonesian Sustainable Palm Oil (ISPO). Kedua kebijakan ini saling berinteraksi. Adanya ISPO membuktikan pada dunia internasional bahwa produksi CPO Indonesia sesuai dengan kaidah-kaidah perlindungan lingkungan (Kartika, 2016). Secara keseluruhan, permintaan CPO UE relatif tetap stabil. Hal ini menunjukkan bahwa masih cerahnya pasar UE bagi Indonesia.

\section{Metode Penelitian}

Sumber data yang digunakan dalam penelitian ini berupa data statistik dari BPS, Kementerian Perindustrian RI, data United Nations Commodity Trade Statistics, dan paper-paper ilmiah yang berkaitan dengan daya saing dan strategi pengembangan kelapa sawit. Data ekspor impor CPO kode HS 151110.

Daya saing dan pangsa pasar ekspor CPO Indonesia dianalisis dengan menggunakan Revealed Comparative Advantage (RCA) dan Market share index. Revealed Comparative Advantage (RCA) digunakan untuk mengukur daya saing keunggulan komparatif. Rumus nilai RCA sebagai berikut:

$$
\mathrm{RCA}=\frac{\mathrm{X}_{i a} / X_{a}}{X_{i w} / X_{w}}
$$

$\mathrm{X}_{\mathrm{ia}}=$ Nilai eskpor komoditi i negara a

$\mathrm{X}_{\mathrm{a}}=$ Total nilai ekspor negara a

$\mathrm{X}_{\mathrm{iw}}=$ Nilai ekspor komoditi i dari dunia

$\mathrm{X}_{\mathrm{w}}=$ Total nilai ekspor dunia

Indeks RCA dirumuskan Indeks $\mathrm{RCA}=\mathrm{RCA}_{\mathrm{t}} / \mathrm{RCA}_{\mathrm{t}-1 .}$ Jika nilai indeks $\mathrm{RCA}$ suatu negara untuk komoditas tertentu memiliki nilai lebih besar dari satu $(>1)$, maka negara yang bersangkutan memiliki keunggulan komparatif di atas rata-rata dunia untuk komoditas tersebut. Sebaliknya, bila lebih kecil dari satu $(<1)$, berarti keunggulan komparatif tergolong rendah untuk komoditas tersebut yaitu di bawah rata-rata dunia. Semakin besar nilai indeks, maka tingkat keunggulan komparatif yang dimiliki semakin tinggi. Perhitungan RCA pada penelitian ini difokuskan pada dua negara penghasil CPO terbesar di dunia yaitu Indonesia dan Malaysia.

Market Share Index. Perhitungan ini digunakan untuk mengetahui bagaimana kondisi pasar minyak mentah kelapa sawit Indonesia di negara tujuan ekspor jika dibandingkan dengan pesaingnya. Nilai market share index (MSI) dirumuskan sebagai berikut:

$$
M S I=X_{i a} / M_{i b}
$$

$\mathrm{X}_{\mathrm{ia}}=$ Ekspor negara a untuk produk i

$\mathrm{M}_{\mathrm{ib}}=$ Impor total produk i di negara tujuan

MSI merupakan presentase relatif impor dari beberapa negara dengan nilai berkisar 0-100. Angka MSI yang semakin tinggi mencerminkan semakin luas pangsa pasar yang dikuasai negara tersebut. Perhitungan MSI pada penelitian ini difokuskan pada dua negara Eropa pengimpor komoditas CPO dari Indonesia, yaitu Belanda dan Itali.

\section{Hasil Analisis}

\section{Analisis Daya Saing CPO Indonesia}

Indonesia dan Malaysia merupakan dua negara penghasil kelapa sawit terbesar di dunia. Daya saing kelapa sawit Indonesia terlihat dari hasil RCA. Perhitungan RCA pada 2 negara produsen $\mathrm{CPO}$ terbesar di dunia, menunjukkan bahwa CPO Indonesia memiliki daya saing ekspor, tetapi nilai indeks rata-rata RCA pada tahun 2007-2014 masih di bawah Malaysia. Kinerja ekspor CPO Malaysia cukup bagus. Hal tersebut didorong oleh kebijakan orientasi ekspor Malaysia serta ekspansi investasi perkebunan 
sawit ke luar negeri, sehingga terbatasnya areal perkebunan sawit yang dimiliki tidak menjadi masalah yang signifikan bagi Malaysia. Sedangkan faktor-faktor yang mendorong daya saing yang dimiliki CPO Indonesia adalah, 1) Luas area perkebunan sawit mencapai 11,44 juta Ha di tahun 2015, merupakan lahan sawit terbesar di dunia, 2)
Indonesia merupakan produsen kelapa sawit terbesar di dunia. Dalam kurun waktu 20082014, nilai ekspor CPO Indonesia selalu di atas Malaysia, 3) Terdapat keunggulan dalam hal biaya produksi, berupa upah tenaga kerja dan faktor produksi yang murah, 4) Produksi komoditas CPO Indonesia telah memenuhi standar nasional dan internasional.

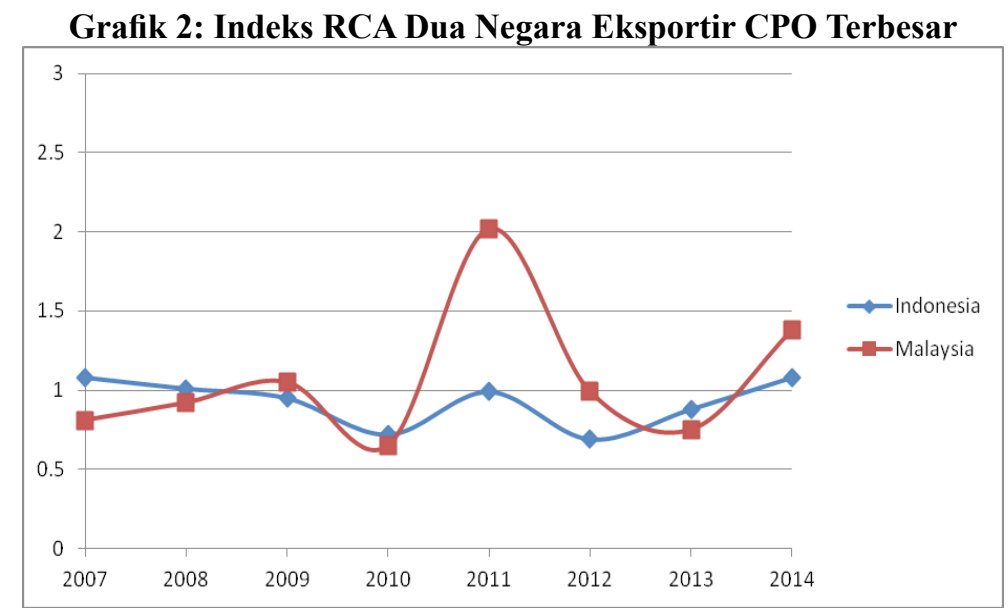

Sumber: UnComtrade diolah.

Dari gambar 1 , terlihat bahwa rata-rata daya saing CPO Indonesia masih kurang dibandingkan Malaysia. Namun demikian, dari grafik terlihat pada tahun 2014 nilai ratarata indeks RCA $>1$ yaitu 1.08 , menunjukkan peningkatan dari tahun-tahun sebelumnya, artinya keunggulan komparatif tergolong tinggi untuk komoditas tersebut pada tahun 2014 yaitu di atas rata-rata dunia. Kinerja ekspor CPO Indonesia cukup bagus pada tahun 2014 karena kenaikan volume ekspor CPO dan turunannya ke negara-negara UE.

\section{Analisis Market Share}

Analisis market share pada pasar UE dilakukan untuk mengetahui lebih jauh posisi komoditas CPO di pasar UE. Sementara pada pasar dunia, analisis pangsa pasar CPO Indonesia secara keseluruhan terlihat pada grafik berikut.

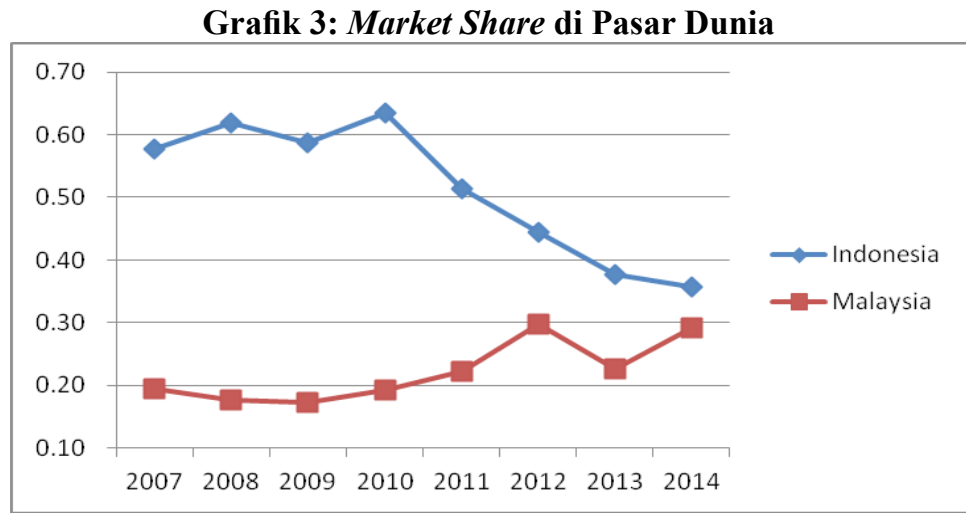

Sumber: UNComtrade diolah.

Pada pasar dunia, terlihat Indonesia tahun 2014. Nilai market share Indonesia tetap menguasai market share CPO hingga masih berada di atas Malaysia sebagai 
pesaing utama. Meskipun demikian nampak penurunan market share mulai tahun 2010. Hal ini seiring dengan menurunnya nilai ekspor CPO Indonesia ke dunia sejak tahun 2011.
Pada pasar UE, analisis pangsa pasar dilakukan untuk mengetahui lebih jauh kondisi dan posisi komoditas CPO. Perhitungan Market Share Index dilakukan pada dua negara importir utama di UE yaitu Belanda dan Italia.

Grafik 4: Market Share di Pasar Belanda

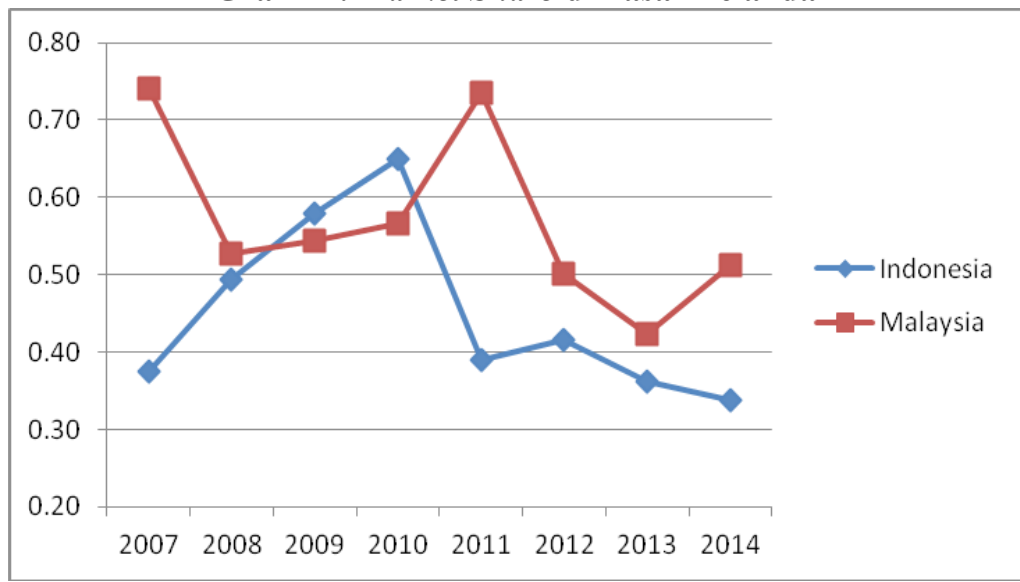

Sumber: UNComtrade diolah.

Di pasar Belanda, kondisi CPO Indonesia hanya unggul pada tahun 20092010 dibandingkan dengan Malaysia. Terlihat bahwa pada tahun 2011 permintaan CPO Indonesia mengalami penurunan hingga tahun 2014 seiring dengan menurunnya jumlah ekspor CPO Indonesia ke dunia. Kondisi penurunan permintaan CPO di pasar Belanda juga terjadi pada Malaysia di tahun
2012-2013. Market share CPO Malaysia mengalami fluktuatif pada titik rendah di tahun 2013. Penurunan ekspor CPO ke Belanda dipengaruhi oleh kebijakan Renewable Energy Directive (RED) 2009. Kebijakan ini membatasi ekspor biofuel berbasis kelapa sawit. RED memberlakuan tarif anti dumping yang berakibat pada penurunan ekspor biofuel Indonesia ke UE.

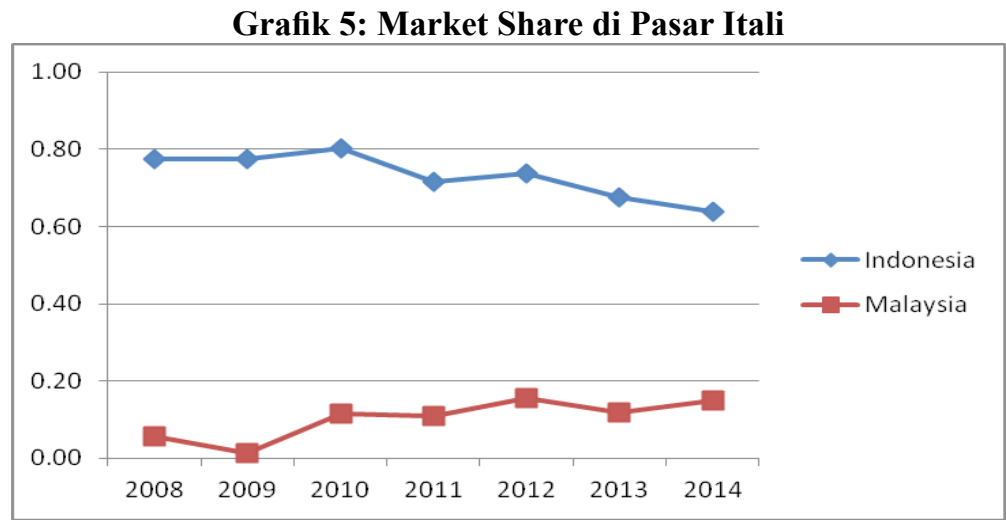

Sumber: UNComtrade diolah.

Pada pasar Italia, kondisi CPO Indonesia periode 2008-2014 berfluktuasi. Di tahun 2008-2010, market share Indonesia relatif stabil dan mengalami peningkatan. Kondisi penurunan market share terjadi pada kurun
2012-2014. Namun demikian, secara keseluruhan pada rentang tahun penelitian, CPO Indonesia menguasai market share pada pasar Itali. Nilai Market Share Indeks Indonesia berada jauh di atas Malaysia. 
Sementara market share Malaysia mengalami naik turun pada periode tersebut, dan posisinya belum mampu menggeser Indonesia.

\section{Penutup}

Indonesia merupakan produsen CPO terbesar di dunia, diikuti Malaysia. Hasil perhitungan RCA pada tahun 2014 menunjukkan ada peningkatan nilai RCA dari tahun sebelumnya. Indonesia mempunyai daya saing ekspor, dengan nilai $\mathrm{RCA}>1$. Kinerja ekspor CPO Indonesia cukup bagus pada tahun 2014 karena kenaikan volume ekspor CPO dan turunannya ke negara-negara UE. Namun demikian, daya saing CPO harus ditingkatkan karena ancaman Malaysia sebagai kompetitor utama.

Dari kedua negara pengimpor $\mathrm{CPO}$ terbesar di UE yaitu Belanda dan Itali, terlihat bahwa Itali merupakan pasar potensial bagi CPO Indonesia karena industri CPO Indonesia mampu menguasai market share pada pasar Itali dalam tujuh tahun terakhir. Kondisi market share Indonesia di pasar Itali jauh di atas pesaing utama, Malaysia. Hal ini menunjukkan Itali merupakan pasar yang cukup stabil bagi Crude Palm Oil Indonesia. Kondisi ini akan memberikan peluang untuk lebih meningkatkan ekspor komoditas CPO ke pasar Itali.

Dalam menghadapi persaingan pada pasar UE, Indonesia hendaknya melakukan peningkatan kualitas $\mathrm{CPO}$, dengan tetap memperhatikan kualitas Standar Nasional Indonesia (SNI) dan Indonesia Sustainable palm Oil (ISPO). Dengan produksi sawit yang ramah lingkungan, diharapkan kebijakan internasional, Roundtable on Sustainable Palm Oil (RSOP) dan Renewable Energy Directive (RED) tidak menjadi hambatan signifikan bagi ekspor CPO ke pasar Eropa. Produktivitas CPO Indonesia dapat ditingkatkan seiring pengoptimalan lahan produksi. Hal ini dikarenakan potensi lahan sawit Indonesia masih memungkinkan perluasan area dibandingkan Malaysia. Selain itu guna meningkatkan nilai ekspor, Indonesia dapat memfokuskan usaha pada industri turunan CPO yang memberi nilai tambah yang tinggi.

\section{Daftar Pustaka}

Balassa, B. 1965. Trade Liberalization and Revealed Comparative Advantage. The Manchester School of Economic and Social Studies 33, No.2.

BPPKP Kementerian Perdagangan. 2013. Analisis Kebijakan Bea Keluar (BK) CPO dan Produk Turunannya. Pusat Kebijakan Perdagangan Luar Negeri. Jakarta.

Dirjenbun dan Kementerian Pertanian. 2015. Statistik Perkebunan Indonesia: Kelapa Sawit 2014-2016. Direktorat Jenderal Perkebunan. Jakarta.

Gapki. 2015. News. Diunduh 3-13 Oktober 2015 dari Http://www.gapki.id.

Kartika, I.T. 2016. Interaksi Kebijakan Renewable Energy Directive (RED) dan Kebijakan Indonesian Sustainable Palm Oil Terhadap Ekspor Kelapa Sawit Indonesia Ke Uni Eropa. Skripsi. Universitas Hasanuddin.

Katalog BPS RI. 2015. Foreign Trade Statistical Bulletin: Exports. BPS. Jakarta.

Nayantakaningtyas, J.S dan Daryanto, H.K. 2012. Daya Saing dan Strategi Pengembangan Minyak Sawit di Indonesia. Jurnal Manajemen \& Agribisnis, Vol. 9 No. 3.

Oil world. Diunduh 3-13 Oktober 2015 dari Http://www.oilworld.biz/app.php

Purnamasari, M., Hanani, N., dan Huang, W. 2014. Analisa Daya Saing Ekspor Kopi Indonesia di Pasar Dunia. Agrise Vol XIV No.1. 
Rahmadi, A dan Aye, L. 2003. Biodiesel from Palm Oil as an Alternative fuel for Indonesia: Opportunities and Challenges. ANZSES.

Salvatore. D. 2007. International Economics. Ninth Edition. Wiley and Sons Inc. USA.

UN Comtrade. Year 2007-2014. Trade Flow. Diunduh 3-13 Oktober 2015 dari Http://comtrade. un.org.

Yacoob, M.R. 2007. An Investigation of the Malaysian Palm Oil Industry's Environmental Strategies, Stakeholders' Pressure, Environmental Effectiveness and Competitive Advantage. Disertation. Univesity of Newcastle. 